\title{
A dose-response effects of tannic acid and protein on growth performance, caecal fermentation, colon morphology, and $\beta$-glucuronidase activity of rats
}

\author{
M. Barszcz ${ }^{1}$, M. Taciak and J. Skomiał \\ The Kielanowski Institute of Animal Physiology and Nutrition, \\ Polish Academy of Sciences \\ 05-110 Jabłonna, Poland
}

(Received 24 June 2011; revised version 22 September 2011; accepted 6 December 2011)

\begin{abstract}
The aim of the present work was to study the influence of tannic acid (TA) and protein level in the diet on fermentation in the caecum of rats, activity of bacterial $\beta$-glucuronidase, and colon morphology. Twelve groups of six male Wistar rats were given either a control diet free of TA or diets containing $0.25,0.5,1,1.5$, or $2 \%$ TA. Diets contained 10 or $18 \%$ of crude protein. Body weight and feed intake were monitored during a 3-week experimental period. Tannic acid reduced protein apparent digestibility and decreased liveweight gain. Both factors affected caecal fermentation and increased volatile fatty acid production. The higher protein level increased the concentration of branched-chain fatty acids. Tannic acid reduced the activity of $\beta$-glucuronidase and affected colonic myenteron thickness. These results indicate that TA may have advantageous effects on the gastrointestinal tract if its amount in the diet does not exceed $1.5 \%$.
\end{abstract}

KEY WORDS: rat, tannic acid, large intestine, morphology, VFA, $\beta$-glucuronidase

\section{INTRODUCTION}

Tannins are secondary plant metabolites with different biological activities and are found in many feeds of plant origin (Mueller-Harvey, 2006). They are known to be antinutritional factors that form indigestible complexes with protein, polysaccharides, and mineral compounds, which may cause a higher flow of

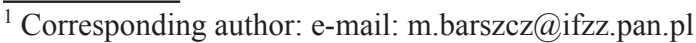


nutrients into the large intestine and thereby influence the molar ratio of volatile fatty acids produced by bacteria (Pastuszewska et al., 2000; McSweeney et al., 2001). Bacteria feed mainly on undigested carbohydrates and protein. Endproducts of carbohydrate fermentation are of importance to animal health. They consist of short-chain fatty acids such as acetic, propionic and butyric acids. The molar ratio of these acids can be changed depending on the type and amount of substrate for fermentation. When carbohydrates are completely fermented, bacteria start to digest protein that reaches the large intestine, which leads to formation of potentially toxic compounds such as branched-chain fatty acids, ammonia, amines and phenols. Their evolution is related to increased risk of colon cancer and it is therefore important to limit bacterial protein degradation (Le Leu et al., 2007). Colonic epithelium may also be exposed to toxins that were neutralized earlier in the liver by conjugation with glucuronic acid. Bacterial hydrolysis of glucuronides is an important enzymatic reaction, catalyzed in the colon by $\beta$-glucuronidase (Gadelle et al., 1985). This enzyme is related to enterohepatic circulation and activation of procarcinogens, carcinogens, mutagens and toxins. Its high activity is found to be a factor of increased risk of developing colon cancer (Jenab and Thompson, 1996). Optimal function of the large intestine is closely related to the digestive processes of intestinal bacteria. End-products from bacterial fermentation may affect intestinal morphology leading to alterations in nutrient absorption and epithelial cell turnover. Diet has the greatest influence on formation of bacterial metabolites and is one of the factors affecting colon morphology (Kuzmuk et al., 2005), but there is a lack of literature about the impact of tannins on caecal fermentation and colon morphology of monogastric animals. Tannic acid, which belongs to the group of hydrolysable tannins, is an example of such a compound. It is toxic to animals when injected into the blood stream or ingested in large doses (Khan and Hadi, 1998), but in small amounts tannic acid has a health-promoting action because of its antimutagenic, anticarcinogenic and antioxidant properties (Lopes et al., 1999; Nam et al., 2001).

The aim of this study was to examine the effect of graded levels of tannic acid and protein in the diet on fermentation processes in the caecum of rats, activity of bacterial $\beta$-glucuronidase, and colon morphology.

\section{MATERIAL AND METHODS}

\section{Animals and diets}

Seventy two ten-week-old male Wistar rats were divided into 12 groups so that the mean body weight in each group was similar $(189 \mathrm{~g})$. The animals were kept 


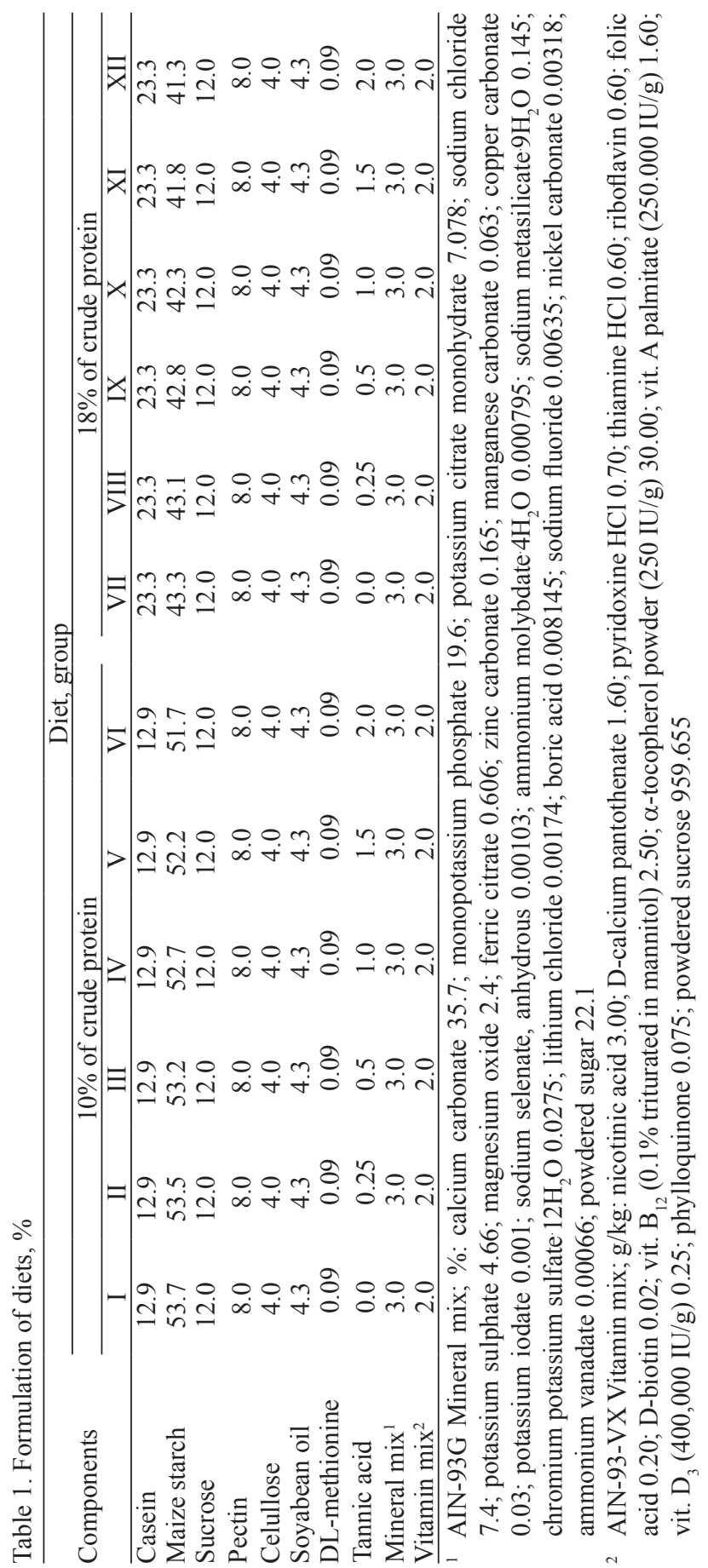


in individual metabolic cages for 21 days under controlled conditions of $22 \pm 1{ }^{\circ} \mathrm{C}$ and $12 \mathrm{~h}$ dark-light cycle and given free access to feed and water.

During the experimental period, body weight and feed intake were monitored. Faeces were collected every day in the $2^{\text {nd }}$ and $3^{\text {rd }}$ week and stored at $-20^{\circ} \mathrm{C}$. After the experiment, rats were anaesthetised by $\mathrm{CO}_{2}$ and killed by cervical dislocation.

Formulation of the diets is given in Table 1 . Feed containing $10 \%$ of crude protein $(\mathrm{CP})$, without the addition of tannic acid (TA), was the control diet. TA powder was purchased from Sigma-Aldrich Ltd. (Poznań, Poland) and mixed with other feed components.

The animal care and experimental procedures were approved by the Local Animal Experimentation Ethics Committee.

\section{Apparent protein digestibility}

Crude protein content in diets and faeces was analysed according to standard methods (AOAC, 1990) using a Kjeltec apparatus (Tecator AB, Sweden) and coefficients of apparent protein digestibility were calculated.

\section{Measurement of volatile fatty acids (VFA)}

Volatile fatty acid concentrations in caecal digesta were determined according to the method of Ziołecki and Kwiatkowska (1973) with the following modifications: caecal digesta was mixed with $4 \mathrm{ml}$ of ultra pure water and $\mathrm{pH}$ was measured using a WTW $\mathrm{pH} / 340 \mathrm{pH}-$ meter. VFAs were converted to their respective sodium salts by adjusting $\mathrm{pH}$ to 8.2 using $1 \mathrm{M} \mathrm{NaOH}$. Samples were stored at $-20^{\circ} \mathrm{C}$. Prior to analysis, samples were thawed at room temperature, thoroughly mixed and centrifuged for $10 \mathrm{~min}$ at $1000 \mathrm{rpm}$ at room temperature. Supernatants were collected and formic acid was added in an amount equal to $10 \%$ of sample volume. After mixing, supernatants were centrifuged for $10 \mathrm{~min}$ at $10000 \mathrm{rpm}$ at room temperature. $500 \mu \mathrm{l}$ of supernatants were transferred into chromatographic vials and mixed with isocaproic acid (internal standard; IS) at a ratio of $15 \mu \mathrm{l}$ of IS to $100 \mu \mathrm{l}$ of supernatant. Samples were analysed in duplicate, using a HP 5890 Series II gas chromatograph (Hewlett-Packard, Waldbronn, Germany) with a flame-ionization detector (FID) and Supelco Nukol fused silica capillary column $(30 \mathrm{~m} \times 0.25 \mathrm{~mm}$ i.d.; $0.25 \mu \mathrm{m})$. Helium was used as the carrier gas with a flow rate of $103 \mathrm{ml} / \mathrm{min}$. The oven was initially kept at $100^{\circ} \mathrm{C}$ for $2 \mathrm{~min}$, then heated at $10^{\circ} \mathrm{C} / \mathrm{min}$ to $140^{\circ} \mathrm{C}$ and held for $20 \mathrm{~min}$. The injector temperature was maintained at $220^{\circ} \mathrm{C}$, while the detector was kept at $250^{\circ} \mathrm{C}$. The total run time was approximately $27 \mathrm{~min}$. Concentrations of individual VFA were estimated in relation to IS using a mixture of VFA standard solutions. 


\section{Measurement of $\beta$-glucuronidase activity}

The $\beta$-glucuronidase assay was based on methods by Fishman (1974) and Jenab and Thompson (1996) with the following modifications: caecal samples $(0.5 \mathrm{~g})$ were homogenized for $30 \mathrm{~s}$ with $5 \mathrm{ml}$ phosphate buffer $(75 \mathrm{mM} \mathrm{KH} 2 \mathrm{PO} 4$ with $1 \% \mathrm{w} / \mathrm{v}$ bovine serum albumin, $\mathrm{pH} 6.8$ at $37^{\circ} \mathrm{C}$ ). Extracts were sonicated ( $2 \times 30 \mathrm{~s}$ at room temperature) and centrifuged for $20 \mathrm{~min}$ at $10000 \mathrm{rpm}$ at room temperature. Supernatants were collected and stored in $1 \mathrm{ml}$ aliquots at $-80^{\circ} \mathrm{C}$. Prior to analysis the supernatants were thawed at room temperature. Reagents were added to disposable polystyrene cuvettes as follows: $200 \mu \mathrm{l}$ ultra pure water, $154 \mu \mathrm{l}$ phosphate buffer and $77 \mu \mathrm{l}$ phenolphthalein $\beta$-D-glucuronide. After $5 \mathrm{~min}$ of preincubation at $37^{\circ} \mathrm{C}, 31 \mu \mathrm{l}$ of the supernatant were added to samples and incubated for $30 \mathrm{~min}$ at $37^{\circ} \mathrm{C}$. The reaction was terminated by the addition of 1540 $\mu \mathrm{l}$ of glycine buffer $\left(200 \mathrm{mM}\right.$ glycine, $\mathrm{pH} 10.4$ at $\left.37^{\circ} \mathrm{C}\right)$. Absorbance was measured at $540 \mathrm{~nm}$ using a UNICAM UV 300 spectrophotometer (Thermo-Spectronic, Cambridge, UK). The amount of phenolphthalein released was estimated using a standard curve for phenolphthalein.

\section{Colon histometry}

Samples of colon tissue were placed in Bouin's solution (mixture of picric acid, formalin and glacial acetic acid at a ratio of 30:15:1, respectively). Subsequently, they were dehydrated, embedded in paraffin and sliced into $5 \mu \mathrm{m}$ sections using a microtome. Two slides were prepared from each sample; each slide contained a minimum of 4 sections that were stained with haematoxylin and eosin. Crypt depth and myenteron thickness (20 measurements per slide) were determined using a light microscope Zeiss Axio Star Plus (Carl Zeiss, Göttingen, Germany) and image analysis program Axio Vision LE Rel. 4,5 (Carl Zeiss, 2002-2005).

\section{Statistical analysis}

Statistical analysis of data followed a block design, with a factorial arrangement of $2 \times 6$, taking into consideration the main effects of protein and tannic acid level (class variables) with an equal number of 6 replicates for each treatment. Data are presented as means and their standard error values. The effect of TA and protein, and their interactions were determined by two-way ANOVA and differences between treatments were analysed post hoc by the Least Significant Differences test using the STATGRAPHICS ${ }^{\circledR}$ Centurion XVI ver. 16.1.03 (Statistical Graphic Corp., 1982-2010) statistical package. In addition, orthogonal polynomial contrasts were used to detect linear, quadratic and cubic effects of TA supplementation on chosen parameters. The effects were considered to be significant at $\mathrm{P} \leq 0.05$ and $\mathrm{P} \leq 0.01$. Trends between $\mathrm{P} \geq 0.05$ and $\mathrm{P} \leq 0.1$ are also presented and discussed. 


\section{RESULTS}

Feed intake did not differ among rats but differences in apparent protein digestibility were noted. The addition of tannic acid caused a significant $(\mathrm{P} \leq 0.01)$ reduction in apparent protein digestibility and this effect was modified by protein level in the diet (interaction $\mathrm{P} \leq 0.01$ ). Apparent protein digestibility for $18 \% \mathrm{CP}$ diets was significantly higher in comparison with diets containing $10 \%$ of $\mathrm{CP}$ (Figure 1). Rats receiving 18\% CP diets had higher liveweight gains compared with rats fed $10 \% \mathrm{CP}$ diets and better feed efficiency (data not shown). Tannic acid decreased liveweight gains $(\mathrm{P} \leq 0.01)$ and differences between control groups and groups fed on diets with 1, 1.5 and $\%$ TA were noticed (Figure 2).

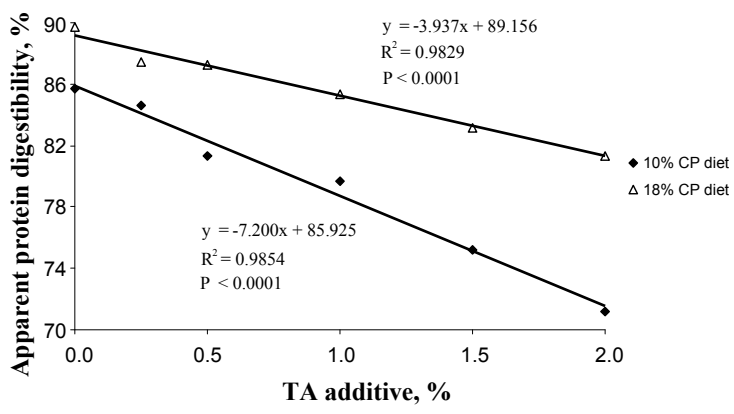

Figure 1. The relationship between the amount of tannic acid (TA) and crude protein (CP) level in the diet and the apparent protein digestibility. Effects of the dietary groups are: TA level $(\mathrm{P} \leq 0.0001)$; $\mathrm{CP}$ level $(\mathrm{P} \leq 0.0001) ; \mathrm{TA} \times \mathrm{CP}(\mathrm{P} \leq 0.0001)$

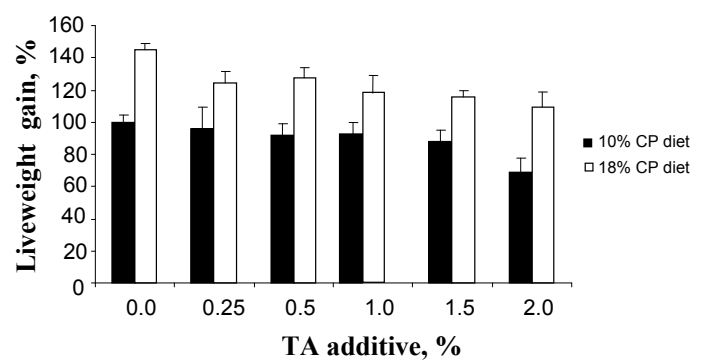

Figure 2. Liveweight gains of rats. Effects of the dietary groups are: tannic acid (TA) level ( $\mathrm{P}=0.006)$; crude protein $(\mathrm{CP})$ level $(\mathrm{P} \leq 0.001) ; \mathrm{TA} \times \mathrm{CP}(\mathrm{P}=0.768)$

Regression analysis showed a directly proportional relationship between the amount of TA in the diet and the relative weight of caecal digesta (Figure 3). 
Significant differences $(\mathrm{P} \leq 0.01)$ were noted between control groups and groups with $1,1.5$ and $2 \%$ TA additive. Rats fed on the diet with $2 \%$ TAdiffered significantly $(\mathrm{P} \leq 0.01)$ from the other groups except for those diets with $1.5 \%$ added TA.

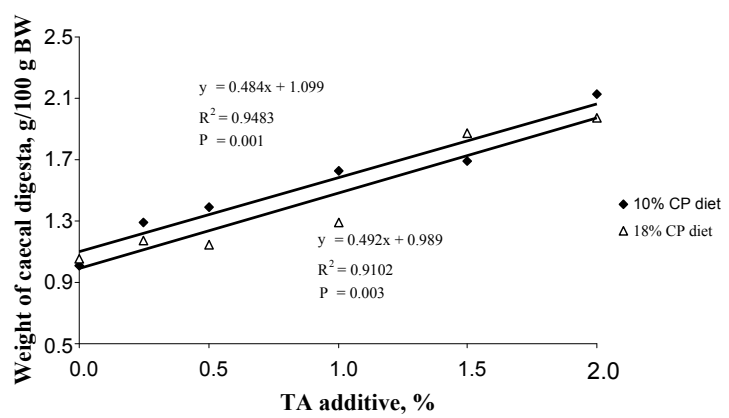

Figure 3. The ralationship between the amount of tannic acid (TA) and crude protein (CP) level in the diet and a relative weight of caecal digesta of rats. Effects of the dietary groups are: TA level $(\mathrm{P} \leq 0.0001) ; \mathrm{CP}$ level $(\mathrm{P}=0.246) ; \mathrm{TA} \times \mathrm{CP}(\mathrm{P}=0.587)$

The caecal pool of VFA (Table 2) was significantly greater in animals fed on $18 \% \mathrm{CP}$ diets than in animals fed $10 \% \mathrm{CP}$ diets. The addition of TA increased the caecal VFA concentration. Significant differences were found between control groups and groups with $1 \%(\mathrm{P} \leq 0.05), 1.5 \%(\mathrm{P} \leq 0.01)$ and $2 \%(\mathrm{P} \leq 0.05)$ added TA.

Table 2. Caecal concentration of volatile fatty acids (VFA) in rats

\begin{tabular}{|c|c|c|c|c|c|c|c|c|c|}
\hline \multirow{2}{*}{ Group } & \multicolumn{2}{|c|}{ Experimental factor, $\%$} & \multicolumn{7}{|c|}{ VFA concentration, $\mu \mathrm{M}$ per caecum } \\
\hline & TA & $\mathrm{CP}$ & $\mathrm{C}_{2}$ & $\mathrm{C}_{3}$ & $\mathrm{i}-\mathrm{C}_{4}$ & $\mathrm{C}_{4}$ & $\mathrm{i}-\mathrm{C}_{5}$ & $\mathrm{C}_{5}$ & $\sum$ \\
\hline I & 0.00 & 10 & 94.3 & 34.6 & 3.1 & 15.8 & 2.1 & 1.9 & 152.0 \\
\hline II & 0.25 & 10 & 123.0 & 29.9 & 3.6 & 17.8 & 2.9 & 2.7 & 180.1 \\
\hline III & 0.5 & 10 & 124.6 & 35.3 & 4.1 & 20.2 & 3.6 & 3.4 & 191.2 \\
\hline IV & 1.0 & 10 & 164.2 & 34.8 & 3.9 & 24.3 & 3.0 & 3.2 & 233.4 \\
\hline V & 1.5 & 10 & 141.8 & 31.0 & 3.5 & 16.6 & 2.7 & 3.6 & 199.1 \\
\hline VI & 2.0 & 10 & 136.8 & 35.5 & 3.9 & 15.8 & 3.7 & 2.3 & 198.0 \\
\hline VII & 0.00 & 18 & 115.6 & 36.1 & 3.7 & 13.6 & 3.2 & 2.9 & 175.1 \\
\hline VIII & 0.25 & 18 & 148.3 & 43.1 & 4.2 & 18.0 & 3.2 & 3.6 & 220.5 \\
\hline IX & 0.5 & 18 & 126.9 & 39.9 & 4.2 & 15.5 & 4.2 & 3.5 & 194.2 \\
\hline X & 1.0 & 18 & 158.2 & 42.4 & 4.1 & 15.9 & 3.4 & 3.5 & 227.5 \\
\hline XI & 1.5 & 18 & 188.2 & 43.8 & 6.4 & 23.4 & 6.5 & 5.8 & 274.2 \\
\hline XII & 2.0 & 18 & 178.2 & 41.3 & 6.8 & 22.5 & 7.0 & 5.5 & 261.3 \\
\hline SEM & & & 6.0 & 1.5 & 0.2 & 0.9 & 0.3 & 0.2 & 8.0 \\
\hline
\end{tabular}

Significance of effects in ANOVA

\begin{tabular}{llllllll}
$\mathrm{TA}$ & 0.017 & 0.990 & 0.002 & 0.535 & 0.006 & 0.072 & 0.046 \\
$\mathrm{CP}$ & 0.055 & 0.013 & 0.000 & 0.884 & 0.001 & 0.004 & 0.030 \\
$\mathrm{TA} \times \mathrm{CP}$ & 0.714 & 0.841 & 0.005 & 0.100 & 0.068 & 0.275 & 0.565 \\
\hline
\end{tabular}

$\mathrm{C}_{2}$ - acetic acid; $\mathrm{C}_{3}$ - propionic acid; $\mathrm{i}-\mathrm{C}_{4}$ - isobutyric acid; $\mathrm{C}_{4}$ - butyric acid; $\mathrm{i}-\mathrm{C}_{5}$ - isovaleric acid; $\mathrm{C}_{5}$ - valeric acid 
In all groups, acetic acid was the major metabolite and made up 62.1 to $69.5 \%$ of total VFA. Addition of 1, 1.5 and $2 \%$ of TA significantly increased the acetic acid concentration compared with control groups. Concentrations of acetic acid increased linearly $(\mathrm{P} \leq 0.05)$ with increasing doses of TA in $18 \% \mathrm{CP}$ diets and exhibited a quadratic trend $(\mathrm{P} \leq 0.1)$ with TA supplementation of $10 \% \mathrm{CP}$ diets, with the largest increase noted for the $1 \%$ TA treatment.

Propionic acid amounted to $18.1 \%$ of total VFA in caecal digesta. The concentration of propionic acid was significantly greater when $18 \% \mathrm{CP}$ diets were fed in comparison with $10 \% \mathrm{CP}$ diets $(\mathrm{P} \leq 0.05)$. Tannic acid had no effect on propionic acid concentration and there were no functional dependencies.

Butyric acid accounted for 9.6 and $8.0 \%$ of total VFA for 10 and $18 \% \mathrm{CP}$ diets, respectively. Based on the ANOVA results, neither TA nor CP level had a significant effect on butyric acid concentration in the caecum, although an interactive trend was noted $(\mathrm{P} \leq 0.1)$. The highest butyric acid concentrations were observed at $1 \% \mathrm{TA}$ for $10 \% \mathrm{CP}$ diets and at $1.5 \% \mathrm{TA}$ for $18 \% \mathrm{CP}$ diets. Orthogonal contrasts analysis showed that addition of TA resulted in a linear increase $(\mathrm{P} \leq 0.05)$ in caecal butyric acid concentration in rats fed diets with the higher level of CP.

Both factors significantly affected $(\mathrm{P} \leq 0.01)$ the concentration of isobutyric acid. An interaction $(\mathrm{P} \leq 0.01)$ between $\mathrm{TA}$ and $\mathrm{CP}$ level was observed. Increasing doses of TA in diets with the higher level of CP resulted in a linear response $(\mathrm{P} \leq 0.01)$ in isobutyric acid concentration with the highest values noted for the 1.5 and $2 \%$ TA additions. In rats fed on $10 \% \mathrm{CP}$ diets, a cubic trend $(\mathrm{P} \leq 0.1)$ was observed with increasing TA level. Taking all groups into consideration, significant differences were noted between control groups and groups with $1.5 \%$ $(\mathrm{P} \leq 0.01)$ and $2 \%(\mathrm{P} \leq 0.05)$ added TA.

Tannic acid and $\mathrm{CP}$ level had a significant $(\mathrm{P} \leq 0.01)$ influence on the isovaleric acid concentration as the mean concentration of this acid was higher in caecal digesta of rats receiving 18\% CP diets than in other groups. Tannic acid modified the effect of CP level on the caecal concentration of isovaleric acid and a trend towards an interaction was observed $(\mathrm{P} \leq 0.1)$. Significant differences were noted between control groups and groups with $1.5 \%(\mathrm{P} \leq 0.01)$ and $2 \%(\mathrm{P} \leq 0.05)$ of TA. As in the case of isobutyric acid, a linear increase $(\mathrm{P} \leq 0.05)$ of isovaleric acid concentration was observed when $18 \% \mathrm{CP}$ diets contained $\mathrm{TA}$, and a cubic response $(\mathrm{P} \leq 0.05)$ was noted for increasing doses of $\mathrm{TA}$ in $10 \% \mathrm{CP}$ diets.

The valeric acid concentration was the lowest. Diets with $18 \%$ of CP increased its concentration in comparison with the $10 \% \mathrm{CP}$ diets. Tannic acid did not have a statistically significant influence on the valeric acid concentration, although functional dependencies were observed: linear $(\mathrm{P} \leq 0.05)$ for $18 \% \mathrm{CP}$ diets and quadratic $(\mathrm{P} \leq 0.1)$ for $10 \% \mathrm{CP}$ diets.

The activity of bacterial $\beta$-glucuronidase decreased significantly $(\mathrm{P} \leq 0.01)$ when diets with TA were fed (Figure 4 ). The lowest $\beta$-glucuronidase activity was 
observed in groups of rats receiving diets with $1 \% \mathrm{TA}$, in which was $67.9 \%$ lower than in the control group. The CP level in the diets did not affect the activity of $\beta$-glucuronidase.

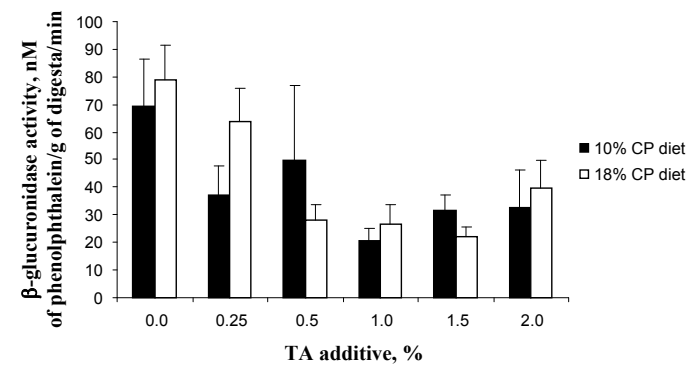

Figure 4. The activity of bacterial $\beta$-glucuronidase in the caecal digesta of rats. Effects of the dietary groups are: tannic acid $(\mathrm{TA})$ level $(\mathrm{P}=0.002)$; crude protein $(\mathrm{CP})$ level $(\mathrm{P}=0.673)$; $\mathrm{TA} \times \mathrm{CP}$ $(\mathrm{P}=0.490)$

Crypt depth in the colon did not significantly differ among rats (data not shown), but in relation to myenteron thickness, significant interactions between TA and CP level were noted (Figure 5). The myenteron was significantly thicker in animals fed on $18 \% \mathrm{CP}$ diets and free of TA than in animals fed on diets with 0.5 and $2 \%$ TA. It also differed from rats receiving diets with $10 \%$ of CP with 0.25 and $1.5 \%$ TA.

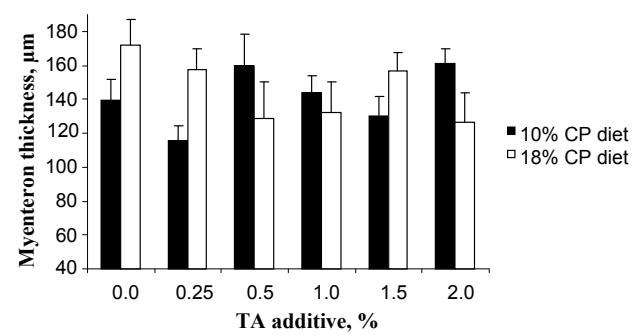

Figure 5. Myenteron thickness in the colon of rats. Effects of the dietary groups are: tannic acid (TA) level $(\mathrm{P}=0.802)$; crude protein $(\mathrm{CP})$ level $(\mathrm{P}=0.612) ; \mathrm{TA} \times \mathrm{CP}(\mathrm{P}=0.023)$

\section{DISCUSSION}

Protein level and the addition of tannic acid (TA) did not affect feed intake. It is generally known that the main dietary factor influencing feed intake in rats is the energy density of the diet, while the protein concentration seems to play a less 
important role. TAs lack of influence may be due to its low concentration which did not reduce palatability, but the chemical structure of TA is also important. Tannic acid belongs to the group of hydrolysable tannins. A bitter taste, which negatively affects voluntary feed intake, is attributed mainly to condensed tannins (Dixon et al., 2005).

Protein and TA level influenced protein digestibility and growth of rats. Their effect may be related to amino acid availability. The negative effects of TA on growth were smaller in rats fed on the $18 \% \mathrm{CP}$ diets in comparison with the $10 \%$ $\mathrm{CP}$ diets. This may be due to a higher amount of $\mathrm{CP}$ available for digestion in the small intestine. The higher apparent protein digestibility coefficients observed in rats fed on $18 \% \mathrm{CP}$ diets support these results.

Nakamura et al. (2001) suggest that TA at a dose of only $0.1 \mathrm{~g} / \mathrm{kg}$ of body weight causes a reduction of liveweight gain of rats. This response may result from a negative influence of TA on nutrient digestibility and absorption. The most TA-sensitive nutrient is protein (Mueller-Harvey, 2006), which can precipitate by binding to tannins. This can lead to the inhibition of enzyme activity and significant reduction of protein and dry matter digestibility (Jansman, 1993). Polyphenolic compounds may also modify brush border membrane proteins resulting in a decrease of nutrient absorption, which may be another reason for liveweight gain reduction in rats (Jansman, 1993).

The increased relative weight of caecal digesta may result from the lower digestibility of nutrients in rats receiving TA in the diets, thereby more intensive bacterial fermentation. Volatile fatty acids are an indicator of bacterial activity in the large intestine. The highest concentration of VFA was observed when $1 \%$ TA was added to $10 \%$ CP diets and $1.5 \%$ TA to $18 \%$ CP diets. The increase of the caecal VFA pool may be attributed to increased fermentation caused by higher amounts of substrates for microflora. This would be in agreement with reduced protein digestibility and increased relative weight of caecal digesta. The relationship between VFA concentration and TA level is not proportional. The caecal VFA pool at 2\% TA additive is lower than at 1 and $1.5 \%$. This may suggest that a TA supplementation of around 1 to $1.5 \%$ could be beneficial for the fermentation processes in the caecum of rats.

Acetic acid was $67 \%$ of the caecal VFA pool. This may probably result from pectin that is a major source of acetate (Pastuszewska et al., 2000) and was added to the diets to stimulate fermentation intensity. Inclusion of TA to the diet caused an increase of acetic acid concentration but did not influence the propionic acid concentration. The effect of TA was more pronounced in rats fed on diets with a higher level of CP, which does not confirm the hypothesis of Bravo et al. (1994) who suggested that TA is an inhibitor of acetic-acid-producing bacteria. 
In the present study, tannic acid decreased protein digestibility, causing a higher amount of protein to reach the caecum, but it did not have a significant effect on butyric acid concentration. This acid is of particular importance as it is a major energy source for colonocytes, determines normal cell phenotype, and prevents the development of colon cancer (Topping and Clifton, 2001). The response in microbial activity in the caecum might suggest a positive effect of 1 and 1.5\% TA, depending on the protein level in the diet.

The higher CP level in the diet increased branched-chain fatty acid (BCFA) concentrations in the caecum of rats. These acids are markers of proteolytic fermentation and derive from degradation of branched-chain amino acids (BCFA) of such as valine, leucine and isoleucine (Hughes et al., 2000). It is likely that the higher amount of protein reaching the caecum and stimulating the development of proteolytic microflora is the reason for the increased concentration of valeric, isovaleric, and isobutyric acids. Some of these important proteolytic species belong to the genera such as: Bacteroides, Propionibacterium, Clostridium, Fusobacterium, Streptococcus and Lactobacillus (Hughes et al., 2000). Results obtained for weaned pigs (Opapeju et al., 2009) shown that animals receiving diets with a lower CP level tended to have a smaller prevalence of the genus Clostridium in their colon digesta compared with pigs fed diets with higher CP levels. Our results indicate that adding $1 \%$ or $1.5 \%$ TA increases the concentration of BCFA in $18 \%$ CP diets, probably as the effect of lower protein digestibility, which was also observed by Le Leu et al. (2007) who used indigestible potato protein as only protein source in rat diets.

Bacteria in the large intestine may produce toxic metabolites, convert bile acids and digest or hydrolyse some drugs. The level of some bacterial enzymes is thought to be a factor affecting colon carcinogenesis. One of these enzymes is $\beta$-glucuronidase. In the present study, the TA level affected $\beta$-glucuronidase activity. The beneficial influence of polyphenolic compounds on $\beta$-glucuronidase activity was also shown by Juśkiewicz et al. (2001) and Zduńczyk et al. (2003). Inhibition is probably caused by formation of a tannin-enzyme complex (Aerts et al., 1999). Another mechanism to decrease $\beta$-glucuronidase activity is the inhibition of specific microflora having a high activity of this enzyme, as suggested by Jurgoński et al. (2008). The ability of TA to modify the intestinal microflora composition was shown by Chung et al. (1998), who reported that TA is an in vitro growth inhibitor for Clostridium perfringens, Bacteroides fragilis, Salmonella typhimurium, Escherichia coli but not for Bifidobacterium infantis and Lactobacillus acidophilus. Roberton et al. (1982) showed that bile is very important in the regulation of $\beta$-glucuronidase activity, and should therefore be taken into account for further studies. 
Histological parameters reflect intestinal environment and are an indication of health status (Lu et al., 2008). Adding TA to the diets did not alter the colon crypt depth of rats. Therefore, it can be assumed that TA does not influence the proliferation, differentiation or functions of colonocytes. Tannic acid modifies the effect of CP level on myenteron thickness, which may to point changes in the passage rate of digesta through the large intestine. Myenteron structure may also be associated with nutrient digestibility, but the results obtained in this study are equivocal and need further research.

\section{CONCLUSIONS}

Increasing the level of tannic acid (TA) decreased protein digestibility and caused a higher amount of undigested protein to reach the caecum, which influenced the amount and profile of volatile fatty acids. The activity of bacterial $\beta$-glucuronidase was influenced only by the level of TA in the diet. Considering microbial activity, it can be supposed that TA in the diet, particularly in the amounts of 1 and $1.5 \%$, may be beneficial for fermentation processes in the caecum of rats. The negative impact on liveweight gains indicates that this compound would be more advantageous for adults than young animals. The necessary condition enabling the use of TA in the diets for rats is an appropriate level of protein.

\section{REFERENCES}

Aerts R.J., Barry T.N., McNabb W.C., 1999. Polyphenols and agriculture: beneficial effects of proanthocyanidins in forages. Agr. Ecosyst. Environ. 75, 1-12

AOAC, 1990. Association of Official Analytical Chemists, Official Methods of Analysis. 15 $5^{\text {th }}$ Edition. Washington, DC

Bravo L., Abia R., Eastwood M.A., Saura-Calixto F., 1994. Degradation of polyphenols (catechin and tannic acid) in the rat intestinal tract. Effect on colonic fermentation and faecal output. Brit. J. Nutr. 71, 933-946

Chung K.-T., Lu Z., Chou M.W., 1998. Mechanism of inhibition of tannic acid and related compounds on the growth of intestinal bacteria. Food Chem. Toxicol. 36, 1053-1060

Dixon R.A., Xie D.-Y., Sharma S.B., 2005. Proanthocyanidins - a final frontier in flavonoid research? New Phytol. 165, 9-28

Fishman W.H., 1974. Methods of Enzymatic Analysis. Vol. II. $2^{\text {nd }}$ Edition. Academic Press, New York, pp. 930-932

Gadelle D., Raibaud P., Sacquet E., 1985. $\beta$-Glucuronidase activities of intestinal bacteria determined both in vitro and in vivo in gnotobiotic rats. Appl. Environ. Microbiol. 49, 682-685

Hughes R., Magee E.A.M., Bingham S., 2000. Protein degradation in the large intestine: relevance to colorectal cancer. Curr. Issues Intest. Microbiol. 2, 51-58

Jansman A.J.M., 1993. Tannins in faba beans (Vicia faba L.) - antinutritional properties in monogastric animals. PhD. Thesis, Wageningen (the Netherlands) 
Jenab M., Thompson L.U., 1996. The influence of flaxseed and lignans on colon carcinogenesis and $\beta$-glucuronidase activity. Carcinogenesis 17, 1343-1348

Jurgoński A., Juśkiewicz J., Zduńczyk Z., 2008. Comparative effects of different dietary levels of cellulose and fructooligosaccharides on fermentative processes in the caecum of rats. J. Anim. Feed Sci. 17, 88-99

Juśkiewicz J., Wróblewska M., Zhaki K., Zduńczyk Z., Hussein L., 2001. Biological activity of faba beans proanthocyanidins. Acta Aliment. 30, 63-69

Khan N.S., Hadi S.M., 1998. Structural features of tannic acid important for DNA degradation in the presence of $\mathrm{Cu}(\mathrm{II})$. Mutagenesis 13, 271-274

Kuzmuk K.N., Swanson K.S., Tappenden K.A., Schook L.B., Fahey Jr. G.C., 2005. Diet and age affect intestinal morphology and large bowel fermentative end-product concentrations in senior and young adult dogs. J. Nutr. 135, 1940-1945

Le Leu R.K., Brown I.L., Hu Y., Morita T., Esterman A., Young G.P., 2007. Effect of dietary resistant starch and protein on colonic fermentation and intestinal tumourigenesis in rats. Carcinogenesis $28,240-245$

Lopes G.K.B., Schulman H.M., Hermes-Lima M., 1999. Polyphenol tannic acid inhibits hydroxyl radical formation from Fenton reaction by complexing ferrous ions. Biochim. Biophys. Acta $1472,142-152$

Lu J.J., Zou X.T., Wang Y.M., 2008. Effects of sodium butyrate on the growth performance, intestinal microflora and morphology of weanling pigs. J. Anim. Feed Sci. 17, 568-578

McSweeney C.S., Palmer B., McNeill D.M., Krause D.O., 2001. Microbial interactions with tannins: nutritional consequences for ruminants. Anim. Feed Sci. Tech. 91, 83-93

Mueller-Harvey I., 2006. Unravelling the conundrum of tannins in animal nutrition and health. J. Sci. Food Agr. 86, 2010-2037

Nakamura Y., Kaihara A., Yoshii K., Tsumura Y., Ishimitsu S., Tonogai Y., 2001. Effects of the oral administration of green tea polyphenol and tannic acid on serum and hepatic lipid contents and fecal steroid excretion in rats. J. Health Sci. 47, 107-117

Nam S., Smith D.M., Dou Q.P., 2001. Tannic acid potently inhibits tumor cell proteasome activity, increases p27 and Bax expression, and induces G1 arrest and apoptosis. Cancer Epidem. Biomarker. Prev. 10, 1083-1088

Opapeju F.O., Krause D.O., Payne R.L., Rademacher M., Nyachoti C.M., 2009. Effect of dietary protein level on growth performance, indicators of enteric health, and gastrointestinal microbial ecology of weaned pigs induced with postweaning colibacillosis. J. Anim. Sci. 87, 2635-2643

Pastuszewska B., Kowalczyk J., Ochtabińska A., 2000. Dietary carbohydrates affect caecal fermentation and modify nitrogen excretion patterns in rats. II. Studies with diets differing in protein quality. Arch. Anim. Nutr. 53, 335-352

Roberton A.M., Lee S.P., Lindop R., Stanley R.A., Thomsen L., Tasman-Jones C., 1982. Biliary control of $\beta$-glucuronidase activity in the luminal contents of the rat ileum, cecum, and rectum. Cancer Res. 42, 5165-5166

STATGRAPHICS $^{\circledR}, 1982-2010$. Centurion XVI ver.16.1.03. Statistical Graphic System by Statistical Graphic Corp.

Topping D.L., Clifton P.M., 2001. Short-chain fatty acids and human colonic function: roles of resistant starch and nonstarch polysaccharides. Physiol. Rev. 81, 1031-1064

Zduńczyk Z., Juśkiewicz J., Wróblewska M., Flis M., 2003. Effect of faba bean seeds with different content of proanthocyanidins on growth of rats, caecal enzyme activity and metabolism indices. Acta Aliment. 32, 161-168

Ziołecki A., Kwiatkowska E., 1973. Gas chromatography of C1 to C5 fatty acids in rumen fluid and fermentation media. J. Chromatogr. 80, 250-254 